\title{
Leonine imagery in C.S. Lewis's series The Chronicles of Narnia
}

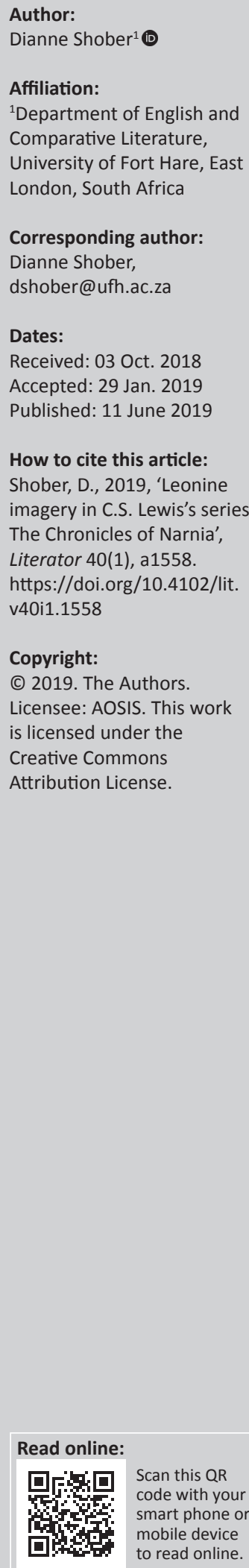

Throughout the centuries, lion images have figured prominently in literature, art, heraldry and statuary. In Chinese art, for instance, lions appear more predominantly than dragons as guardians of buildings and temples, whereas across Europe, warriors surged across continents conquering under the image of the roaring lion emblazoned on their monarchs' flags. Furthermore, numerous cultures and religious traditions symbolically embody their rulers, both divine and temporal, using leonine imagery. Through an investigation of this imagic representation, this article will explore the selection of the lion, Aslan, as the spiritual depiction of the Christ-figure in C.S. Lewis' series The Chronicles of Narnia.

Keywords: Imagery; symbolism; lion; spirituality; tradition; literature; C.S. Lewis.

\section{Introduction}

C.S. Lewis continues to entrance generations of readers by leading them through the mystical wardrobe into his magical kingdom of Narnia, ruled by the magnificent kingly lion Aslan. I read this delightful fantasy series to my children decades ago and was captivated with the imaginative and textual reality of a world and a king whose face, voice and character I could envision through a symbolic form which I, like so many others, could easily identify. Lewis ruminated on this tale from the time he was 16 when the image of a faun carrying an umbrella in a snowy wood captured his imagination, but the story, he states, all came together when 'suddenly Aslan came bounding into it' (Jacobs 2005:247). Aslan, in his leonine form, characterised many of the spiritual elements Lewis intended to weave into his Narnian series, portraying as he did the multiple figures of Creator, Saviour, Deliverer and Ruler. Some, like the Harry Potter author J.K. Rowling who 'adored' the Narnia books because she did not think 'C.S. Lewis was especially preachy' (Renton 2001), have resisted the religious symbolism stitched into the Narnia series, disputing that there exist any elements of the divine in the stories; yet ' $r$ reading them now', Rowling admits, 'I find that his subliminal message isn't very subliminal at all'. Lewis's friend Owen Barfield (1989) highlights this fact when he writes 'somehow what he thought about everything was secretly present in what he said about anything'.

\section{The value of myth}

Lewis, a respected philosopher, professor and apologist invested his life in studying the power of myth and imagination, stating: 'The value of myth is that it takes all the things you know and restores to them the rich significance which has been hidden by a veil of familiarity' (Lewis 1966a). On writing to his friend Arthur Greeves concerning the potential of imagination, Lewis (1979) asserts:

For me, reason is the natural organ of truth; but imagination is the organ of meaning. Imagination, producing new metaphors or revivifying old, is not the cause of truth, but its condition. (p. 477)

Bruce Edwards (2005) contends that:

... [f]rom an early age, Lewis had had a precocious interest in the transcendent, which is to say, the unshakable, the real and sought through the twin organs of imagination and reason, through nature and the outside world, as well as through books and his inner world to apprehend the truth. (n.p. [author's emphasis])

In love with the richness of symbols and the literary use of images, Lewis sought an established image that would effectively represent a ruler beyond Camelot proportions to encompass timeless, almost mythological, elements of the divine. As such, this article will explore Lewis's use of lion symbolism to express the metaphorical Christ-figure and Aslan's embodiment of his manifold divine roles. 


\section{The lion image}

From the 5th century works Aesop's Fables, the lion has been allocated the title 'King of the Beasts', enabling readers to associate him with this ruling authority, at least in the animal kingdom. Indeed, across continents and cultures, animals have been used to represent deities and endowed with supernatural powers. Ladner (1975:733) states that 'from the very beginnings of human consciousness animals were regarded by men as being among the most powerful influences surrounding them for good and evil'. For instance, among some African tribes such as the Igbos in the eastern part of Nigeria, the python is worshipped for its healing powers, symbolisation of eternal life and representation of ancestral spirits. Similarly, the Mpondomise tribe of the AmaXhosa have a snake totem called uMajola and should a snake enter a member's home the occupants will pronounce blessings over it saying (Bongela 2001):

You are a snake of good fortune and bringer of health and affluence to this Ngwanya home. We all hail you in unison saying 'Good day to you, Jolinkomo! Your presence is a source of health and inspiration to us. (p. 58).

The Phakathi clan of the AmaXhosa has instead esteemed the leopard totem that will appear in times of ancestral celebration or to offer assistance in crisis. Likewise, for those of the Hindu faith, the Brahman cow is graced with divine properties and afforded reverence as are the monkey and elephant, whereas in Korean folkloric tradition, the white tiger is the harbinger of the divine spirit, symbolising courage and power and repelling evil forces (Ayres 2016).

In the Christian Bible, the Christ is represented as both the 'Lion of Judah' and the 'Lamb of God'. However, for the purpose of Lewis's stories, the gentle, defenceless lamb is an inadequate animal form in which to embody unmatchable strength and power to create, deliver and pre-eminently rule. Yet, Lewis even encapsulates the lamb image at the conclusion of the third book of his Chronicles series for when Edmund and Lucy have achieved their quest to reach the end of the Narnian world, a lamb invites them to a fish feast. While it is advising them, the lamb transforms into the leonine form of Aslan (Lewis 1970h:215), thereby incorporating both recognised religious images.

\section{Lewis's leonine imagery}

Lewis, an apologist, understood the importance of using symbols to express complex religious concepts. Plato, the philosopher quoted by Lewis' character Professor Digory Kirke ('It's all in Plato, all in Plato: bless me, what do they teach them at these schools') in the final book of the series (Lewis 1970d:170), defines symbols as 'true thoughts concerning things men know nothing about'. They act as 'keys to a lost language' that we cannot audibly hear or comprehend, but that we imaginatively and intuitively respond to (Stegmann, Coursodon \& Miller 1972:5). Portraying the magnificent lion as king of the beasts enables Lewis to represent both the divine and animal form of that noble position and performs the dynamic function of the symbol unifying two realities not immediately assimilable' (Stegmann et al. 1972:12).

When Lewis selects the majestic lion, Aslan, as his insuperable protagonist in his seven-book series The Chronicles of Narnia, he is acting upon a long history of leonine imagery. Like Spenser's lion symbolism in The Faerie Queene, an author whom Lewis critically admired, Lewis chose the lion for its traditional and spiritual representation of a divinely noble animal dispensing both justice and love (Alkaaoud 1984). Lion imagery has an evocative power to create in the minds of the readers the wonders of envisioning a recognisable and revered physical form with the divine, invisible nature. Marotti (1965:77) calls images 'palpable vehicles of meaning'. Frink agrees, stating that the 'imagistic shorthand' of symbols elicits an emotional response, stirring a consciousness and belief that has evaded satisfactory expression while representing 'concepts that we cannot define or fully comprehend' (Frink 1987:13). Huberman (1988) contends that 'lions are the link between the earthly elements and infinite, celestial and metaphysical' universe (p. 28) and are 'associated with the powers of the Almighty' (p. 54). Slotten (1965) furthers Huberman's argument by enunciating the symbolic identification of 'the relation of the Master of Animals and the High-God' (p. 295).

When Aslan is initially introduced to the children in the first book of the series The Lion, The Witch and the Wardrobe, the leonine symbolism is made clear:

Aslan a man! Certainly not. I tell you he is the king of the wood and the son of the great Emperor-Beyond-the Sea. Don't you know who is the King of the Beasts? Aslan is a lion - the Lion, the great Lion. (Lewis 1970e:75).

The awesome beast in Lewis's tales comes bounding from his imagination and onto the pages of his fantasies with all the magnificence to be expected of such a noble animal:

For when they tried to look at Aslan's face they just caught a glimpse of the golden mane and the great, royal, solemn, overwhelming eyes; and they found they couldn't look at him and went all trembly. (Lewis 1970e:123)

It is postulated that linking the symbolic role of the lion to the divine enhances the understanding and acceptability of a concept clouded by emotional and intellectual doubt and distance. This symbol then serves to unify two distinct realities that are not immediately or easily assimilated. Lewis explains it thus:

I thought I saw how stories of this kind could steal past a certain inhibition which had paralysed much of my own religion in childhood. Why did one find it so hard to feel as one was told to feel about God or about the suffering of Christ? I thought the chief reason was that one was told one ought to. An obligation to feel can freeze feelings. And reverence itself did harm. The whole subject was associated with lowered voice, as if it were something medical. But supposing that by casting all these things into a magical world, stripping them of their stained glass and Sunday school associations, one could make them for the first time 
appear in their real potency? Could one not thus steal past those watchful dragons? I thought one could ... (Sibley 1994:68)

He was as it were attempting to combine myth with fact as he explains in his essay 'Myth became fact' from his book God in the Dock (Lewis 1970a). Lewis' own childhood was devoid of emotional sentiment. The early death of his beloved mother and the pronounced distance from his taciturn father were some of the dragons of his youth that caused Lewis to disavow religious faith. Yet, he assuaged his isolation by absorbing himself in a vast array of literary texts, particularly stories of enchantment and heroic myths which served to inflame his imagination to write fantastical stories of a brave armour-clad mouse, a character that bursts into Lewis's third Narnian book The Voyage of the Dawn Treader as the intrepid yet devoted Reepicheep.

Lewis' road to creative genius was a long, hard and at times lonely journey through years of adamant atheism before submitting reluctantly to faith under the tutelage and mentorship of his colleague and friend J.R.R. Tolkien. The discussion that ultimately led to his conversion interestingly centred on metaphor and myth. Lewis wrote of it later (Sibley 1994):

What (Hugh) Dyson and (J.R.R.) Tolkien showed me was that if I met the idea of sacrifice in a Pagan story I didn't mind it at all: again, that if I met the idea of a god sacrificing himself to himself I liked it very much and was mysteriously moved by it: again, that the idea of the dying and reviving god similarly moved me provided I met it anywhere except in the Gospels. (p. 51)

Lewis came to appreciate the gospel message of Christ's death and resurrection presented in the myths he already loved, explaining his intellectualised acquisition of faith as follows (Sibley 1994):

The story of Christ is simply a true myth: a myth working on us in the same way as the others, but with the tremendous difference that it really happened: and one must be content to accept it the same way, remembering that it is God's myth where the others are men's myths: i.e. the Pagan stories are God expressing Himself through the minds of poets, using such images as He found there, while Christianity is God expressing Himself through what we call 'real things'. (p. 51)

It was this same myth that Lewis constructed in the Narnian series in order to reveal the 'real things'. He created a simple yet profound apologue which asks readers to take the elements of the supernatural and assimilate them as real. By creating a world beyond our own, Lewis transports his readers to a place where the communication barrier between animals, human and the divine is non-existent. Lewis, a man who delighted in visually rich metaphors, created significant, established symbols to assist his readers in understanding complex metaphysical concepts by representing them in identifiable and acceptable forms. Initially, Lewis admits that he did not know where the lion came from although it had captured his dreams for some time. Likely the image plied his imagination from the medieval literature that he loved and his years of dedicated research which resulted in such published works as The Discarded Image (Lewis 1967), and Studies in Medieval and Renaissance Literature (1966b), as well as the works of other admired writers such as Charles Williams who wrote The Place of the Lion (1931). As a scholar impassioned by the texts of the ancients and an author who was 'extraordinarily receptive to the voices and styles of his favourite writers' (Jacobs 2005:200), Lewis crafted Aslan's leonine symbolic form and physical shape from his literary and imaginative experiences, and 'once (Aslan) was there he pulled the whole story together, and soon He pulled the six other Narnian stories in after Him' (Jacobs 2005:247).

\section{The tradition of leonine imagery}

When Lewis chose the lion as his pivotal character, he was following a long-standing tradition of envisioning this animal in a kingly, even divine, role. Throughout the centuries, lion images have pranced across our literary pages and been handcrafted by sculptors into magnificent beasts guarding tombs, palaces and museums. In ancient Jewish art, lions are depicted in a protective role, guarding the Holy Ark or at the entrances to chapels, as well as in many mosaics dating from the early Byzantine period (Lions in Jewish Art 2005). King Louis XIV of France, imagining himself as great as the Pharaohs, placed lion images throughout his golden Sun palace. Lion statues guard Nelson's column in London's Trafalgar Square and four large lions are prominently displayed as if fiercely protecting the entrance to the Britannia Bridge in Wales. Sculpted lions even crossed the Atlantic to grace the entrance of the New York City Library or to guard the Grant Memorial.

Nor was it only stone creations that were designed to defend a site. French archaeologists discovered a mummified lion in a skeleton-strewn tomb in the Nile Valley. The body of the animal was strategically placed facing the rising sun with its head pointing northward in a position both of defence and deference. Its discovery within a sacred Pharaonic site confirms that lions were one of the animals worshipped by the final reigning pharaohs ('Mummy Shows Pharaohs Worshipped King of Beasts', 2004). Although this mighty feline has long been revered for its strength and agility, the Greeks recognised the lion's domestic, unifying nature citing their predisposition to live in harmonious tribal societies. As communities developed laws to live in peaceful co-existence, the lion came to symbolise law and justice. Patricia Warren (2000) in her article 'King of Beasts: Manipulation of the Lion Symbol by Patriarchal Culture' writes:

Different ancient names for the Goddess of Freedom and Justice

- Libra of the Romans, Freya of the Tutons and Maat of the

Egyptians - all refer to the lion in some cognate way. (p. 73)

... a point illustrated through the Greek word for 'the people' laos, a cognate of laon, a word for lion.

The Egyptians deified the lioness in Sekhmet the lion goddess of healing, recognising the female's motherly devotion to her cubs and care for her family, but it was the maned male that was heralded as the leader of the pride and whose image 
came to symbolise royalty, and Rew, a Middle Egyptian word for lion, links the animals directly to the throne of Egypt (Warren 2000:74).

For the tribal peoples of the Middle Eastern region where life was treacherous and survival uncertain, the lion came to symbolise bravery and prowess and many tribesmen believed that they could capture these qualities by adopting the leonine title. Hence, in Persia where the word for lion is shir, there are many titled Shir Ali or Alishir or Shir Mohammed. For the Turks, the word 'lion' is Aslan, the name chosen by Lewis for his leonine king in the Narnian series. Furthermore, the cultural group he portrays in a vaguely disguised way as the exotic but cruel Calormenes in the fifth book The Horse and His Boy descriptively represents the Turkish people.

The Hebrew language also has numerous constructs of the word lion and its name appears in one form or another over 130 times in the Christian Bible signifying such ideals as courage, justice, dignity, power and ferocity ( 'Animals in the Bible' 2005). For the Israelites of the Old Testament, their word for lion - lev - became incorporated into the third book of the Pentateuch, Leviticus, a book that records the laws revealed to Moses by Yahweh. The priests, selected to deliver the laws and orchestrate the worship and sacrifice for the Israelites, were chosen from the tribe of Levi further solidifying the symbolic connection of the word lion with the concepts of divine instruction, guardianship and justice. Although the Levites officiate the laws, the tribe of Judah is divinely allocated rulership of the Jewish people, yet the connection to the kingly lion continues. The patriarch Jacob blesses his son Judah with the pronouncement that he is like a lion's cub (New International Version [NIV], Gn 49:9,10), signifying his place of power and dominion within the family genealogy. Generations later, the revered King David, whose 'heart is as the heart of a lion' (2 Sm 17:1), is selected from the bloodline of Judah, fulfilling the promise that the rulers of Israel would emerge from this tribe. The perpetuation of this divinely ensconced kingly rule is to carry through their Messiah, the King of the Jews, who is also to spring from this tribe, a fact said to be realised in Christian teaching which declares that Jesus Christ is the 'Lion of Judah' (Rv 5:5) sent to free all people who receive him as their king.

Thus, it is likely that the prevailing force of Christianity sweeping across Europe carried the symbol of the ruling lion with it. As early as 496, Clovis I, a new convert to Christianity, was appointed protector of the new religion and titled the 'new Constantine' or emperor of the Roman Empire (Warren 2000:76). The impact of this religion is symbolically represented by the images of power and authority selected by the empire's offspring. Lions appeared on the coat of arms of many European countries, including Great Britain, Denmark, Spain, Holland, Bohemia and Saxony, as well as other smaller countries. In 1066, Duke William of Normandy triumphantly crossed the English Channel under the proud banner of two golden lions on a blood-red background.
His son Henry I ruled under the shield of the lion, and a century later, Edward II had over 225 lion banners in his heraldry.

Nor was the lion only representative of rulership in Europe. African tribes also adopted the lion as a symbol of kingship. The king of Swaziland is entitled Ngwenyama which literally means lion (Kuper 1973:613). The Swazi emphasises the lion's bravery, strength and cleverness as the reason this animal was chosen to symbolise the role of king. For the Swazi, the male lion, with his twin ruler the female elephant, is awesome in his formidable and fearless character, one who attacks with purpose not sport, all qualities that the Swazis desire their ruler to emulate.

Given the numerous presentations of lions in language, art and heraldry as symbols of nobility, strength and justice, it is not surprising to see these images translated into literary forms and oral narratives. In ancient Greece, a slave and storyteller known as Aesop composed nearly 700 moral fables. At least 35 of his tales illustrate lions in the role of king of the beasts whose strength is recognised, revered and at times resented by the rest of the animal kingdom. Medieval literature portrays the lion as the divinely appointed ruler who governs and controls, upholding just laws that will bring order and truth into a chaotic world. Spenser, in his work The Faerie Queene, describes King Arthur as a lion who defeats the lawless Turpine through his supreme physical strength and courage, and succeeds as the ultimate victor because he has been divinely allocated the royal position of ruler (Marotti 1965:69).

Catholic tradition, expressed by paintings and texts, symbolises the lion as the authoritative escort to people of exemplary qualities. Saint Jerome is often portrayed with his constant leonine companion. Legend states that the kindly saint cared for the wounded animal and, in gratitude, the lion remained his faithful attendant for the remainder of its life. As a result of this tale, Saint Jerome came to be artistically represented by a lion in order to symbolise the force and strength of this great spiritual father's noble character (Ring 1945:188).

In a more humorous vein, Cervantes' infamous character Don Quixote attempts to provoke a duel with a lion only to have the beast lie down passively, almost nonchalantly, at the errant knight's feet. Scholars, examining this comical episode, conjecture that Cervantes adopted the lion in its traditionally symbolic role 'of recognising and deferring to divinely ordained royalty and rewarding virtuous qualities of those who observe religious and moral laws' in order to mock Quixote's ridiculous attempt at bravery (Rogers 1985:12). Through such intertextual comparisons, lions are often portrayed in a symbolic role to represent specific qualities that translate acknowledged virtues and divine qualities.

\section{The multiple personas of the leonine Christ-figure}

Thus, by selecting a lion - a magnificent creature already associated with power and nobility - to portray his biblical 
Christ-figure Aslan in The Chronicles of Narnia, Lewis seeks to project the divine in a recognisable and understandable form. Lewis was an impassioned Renaissance man whose reading and experiences placed him imaginatively and intellectually in the Old Western Culture. As he argued in other texts he authored, Lewis insisted on 'using the appropriate image to represent a divine mystery' (Jacobs 2005:254). He lived in a world beset with modernism and the horror of two world wars. To avoid people's attempt to rationalise or reject the divine, and thus as George MacDonald, an author who greatly influenced Lewis' thought and writing, said 'spoil countless precious things by intellectual greed' (quoted in Goodwin 2004:12), Lewis transported his readers to a mythological world where the unknown can be defined, embraced and given substance. As the impetuous but trusting Lucy exclaims 'Oh you're real, you're real! Oh Aslan!', as she throws her arms about his neck (Lewis 1970e:150).

A recent biographer Alan Jacobs (2005) who wrote about the life and imagination of Lewis stated that:

Lewis's mind was above all characterised by a willingness to be enchanted ... his willingness to accept a world made by a good and loving God and (in some ways above all) his willingness to submit to the charms of a wonderful story. (p. xxi)

Lewis's own vivid, child-like imaginings helped him appreciate the power of the visual image and assisted him in creating rich and appealing texts of mythological events that would aid young readers in assimilating challenging theological material. In his Letters to Malcolm, Lewis (1964) explains the difficulty of bridging the spiritual and the natural:

Talk of meeting (God) is, no doubt, anthropomorphic, as if God and I could be face to face, like two fellow creatures, when in reality $\mathrm{He}$ is above me and within me and below me and all about me. That is why it has to be balanced by all sorts of metaphysical and theological abstractions. (p. 21)

Lewis portrays Aslan as a Christ-figure in both austere and loving ways. His arrival is always majestic and perfectly timed to deliver from trouble as in his climatic appearance at the height of the battle against the White Witch in The Lion, the Witch and the Wardrobe or the crucial moment in the war against the Calormenes in The Last Battle. Similarly, he arrives to soothe, comfort and protect when the emotional or physical need is the greatest such as Shasta's frightful midnight journey in The Horse and the Boy. Like the physical lion he represents, Aslan is not tame and his roars act as a symbol of his divine power 'to deliver either punishment or salvation' (Huberman 1988:53). Thus, Aslan roars mightily as he calls his troops for battle, roars with joy when his life is renewed, growls warningly when Lucy delays in delivering his healing vial to the wounded and dying, yet nuzzles softly when welcoming or calming his anxious children. Still, he always maintains a majestic, imperial stance as Jill Pole realises when she meets him in The Silver Chair and asks tremulously: 'Do you eat little girls?' and he delivers a forthright reply: 'I have swallowed up girls and boys, women and men, kings and emperors, cities and realms' (1970g:17). This portrayal was not designed to create distance between Aslan and his friends, but to instil an awesome, reverent fear of his greatness and glory, similar to the effect of his terrifying roar at the evil impertinence of the White Witch or his warning growl at any attempted dishonesty by the children. By incorporating the qualities of a real lion with the symbolic qualities associated with the lion of imagery, Lewis represents Aslan as the Christ-figure in a visual almost tangible way.

The picture of the gospel Christ is further conveyed when Aslan sorrowfully trudges to the Stone Table to willingly lay down his life to save the treacherous Edmund. The Witch has demanded the blood of the traitor, reminding Aslan 'that for every treachery I have a right to kill' (Lewis 1970e:139). Lewis continues the gospel narrative as he portrays the power of the resurrected Christ when Aslan is magnificently, miraculously restored: 'There, shining in the sunrise, shaking his mane (for it had apparently grown again) stood Aslan himself' (Lewis 1970e:159). In uncomplicated and perceptive language, Lewis (1970e) has Aslan explain the supernatural event:

... the Witch knew the Deep Magic, there is a magic deeper still which she did not know. Her knowledge goes back only to the dawn of time. But if she could have looked a little farther back, into the stillness and the darkness before Time dawned, she would have read there a different incantation. She would have known that when a willing victim who had committed no treachery was killed in a traitor's stead, the Table would crack and Death itself start working backwards. (p. 160)

Like Christ, Aslan's self-sacrifice saved the sons of Adam and daughters of Eve as well as all the Narnian creatures and destroyed the wintery, wicked reign of the evil White Witch.

At the end of the third book in the Narnian series The Voyage of the Dawn Treader, Lewis unites Aslan, the lion king of the magical world of Narnia to the children's own world and creates an even more meaningful association to the scriptural Christ. Aslan instructs the children that they are too old to return to Narnia; they must now draw close to their own world. This news is greeted with dismay as the children will gravely miss him. He reassures them that he exists in their world, too. 'But you shall meet me, dear one.' 'Are you there, too, Sir', said Edmund. 'I am', said Aslan:

But there I have another name. You must learn to know me by that name. This was the very reason you were brought to Narnia, that by knowing me here for a little, you may know me better there. (Lewis 1970h:216)

In this segment, Lewis confirms the presence of Aslan in the children's home world and endows Aslan with the Christological title 'I $\mathrm{am}^{\prime}$ to illuminate the symbolic connection to Christ illustrated in numerous scriptural references in the book of John in the New Testament. Lewis reiterates this linkage in the fifth book of the series The Horse and His Boy when Shasta asks Aslan 'Who are you?', Aslan replies thrice 'Myself' (Lewis 1970c:159). When Jesus spoke 
these words to the religious leaders, they wanted to stone him; however, Lewis describes how Shasta's heart tingled with contentment and excitement at Aslan's enunciation, emphasising the concept that only a child-like heart will find him.

Aslan assumes the role of Creator in Lewis sixth book The Magician's Nephew singing into existence every portion of the Narnian world:

The Lion was pacing to and fro about that empty land and singing his new song. It was softer and more lilting than the song by which he had called up the stars and the sun; a gentle, rippling music. And as he walked and sang the valley grew green with grass. It spread out from the Lion like a pool. It ran up the sides of the little hills like a wave. In a few minutes it was creeping up the lower slopes of the distant mountains, making the young world every moment softer. (Lewis 1970f:104)

Later in that tale, Aslan becomes the compassionate Healer when he gives fruit from his Narnian garden Paradise to Digory to revive his ailing mother in England. Aslan's Christlike heart of forgiveness and open arms of acceptance are illustrated in Lewis' final book. In The Last Battle, the virtuous Calormene Emeth whose name in Hebrew means truth is welcomed by Aslan into his eternal country, the real Narnia, even though he had served the evil god Tash. Emeth, although convinced he will be slain for his blasphemy, bows in reverent worship before the Lion and is amazed at Aslan's merciful and loving reception. 'The Glorious One bent down his head and touched my forehead with his tongue and said "Son thou art welcome". . Aslan explains:

I take to me the services which thou hast done for him, for I and (Tash) are of such different kinds, that no service which is vile can be done to me, and none which is not vile can be done to him ... unless thy desire had been for me though wouldst not have sought so long and so truly. For all find what they truly seek. (Lewis 1970d:165)

... an echo of Jesus' words in Matthew 6:33: 'Seek first His kingdom and His righteousness and all these things will be given to you'.

At the end of The Last Battle, Lewis continues the mysterious transformation when he anthropomorphises Aslan into yet another undefined form. 'The term is over: the holidays have begun. The dream is ended: this is the morning' And as He spoke He no longer looked to them like a lion; but the things that began to happen after that were so great and beautiful that I cannot write them (Lewis 1970d:183).

In biblical numerology, the number 7 symbolises completion and it is through seven tales that Lewis reveals seven aspects of Jesus' character in his counterpart Aslan and sweeps the reader from the creation story in Genesis to the apocalypse in the Revelation. Each tale in the Narnian series presents Aslan with a different aspect of Christ's deity. In The Lion, The Witch and the Wardrobe, Aslan is the Saviour, sacrificing himself to save the traitor Edmund. In Prince Caspian (Lewis 1970b), Aslan is the authoritative Teacher who instructs his disciples to 'Come and follow me'. The Voyage of the Dawn Treader reveals Aslan as the Redeemer, freeing the rebellious Eustace from his dragon scales, and transforming him into a new person. Aslan becomes the wonderful counsellor in The Silver Chair guiding the children to their required destination. In The Horse and His Boy, Aslan is portrayed as the comforter, soothing Shasta's midnight fears. The Magician's Nephew casts Aslan as the creator of the new Narnian world, singing every blade of grass, flowering tree and talking and non-talking animal into existence. Finally, in The Last Battle, Aslan is the Mighty God, ushering his beloved into his eternal country that the brave mouse Reepicheep and the others have earnestly sought.

By crafting the Christ-figure in the well-known and traditional role of king of the beasts, Lewis creates a correlation in the minds of the readers with the person of Jesus Christ without blatantly mentioning his name or the doctrine of Christianity. He has, in essence, slain the mythical dragon that guards the minds of child and adult, innocent and sceptic to present them with a theological construct that would have been initially unfathomable or unpalatable. Lewis explains that Aslan:

... is an invention giving an imaginary answer to the question: What might Christ have become like, if there really were a world like Narnia and he chose to be incarnate and die and rise again in that world as He has actually done in ours? ... Allegory and supposals mix the real and unreal in different ways. The Incarnation of Christ in another world is mere supposal; but granted that supposition, he would really have been a physical object in that world as he was in Palestine and His death on the Stone Table would have been a physical event no less than his death on Calvary. (Goodwin 2004:6)

Did Lewis accomplish his task of creating the essence of Christ in the magnificent and austere form of the kingly lion Aslan? The letters from readers around the world asking for Aslan's name in our world, like the one from an 11-year-old American girl, would suggest yes. To inspire the wonder of imagination and an earnest quest for understanding, Lewis responded to her query as follows:

As to Aslan's other name, well, I want you to guess. Has there never been anyone in this world who (1) arrived at the same time as Father Christmas; (2) said he was the son of the great Emperor; (3) gave himself up for someone else's fault to be jeered at and killed by wicked people; (4) came to life again; is sometimes spoken of as a Lamb ... Don't you really know His name in this world? Think it over and let me know your answer! (quoted in Goodwin 2004:10)

Many did think it over, yet to Lewis' surprise, it was most often children and not adults who understood the symbolic connection. For Lewis, their intellectual greed had spoiled the precious things and for them, he wrote a warning:

We may ignore, but we can nowhere evade, the presence of God. The world is crowded with Him. He walks everywhere incognito. And the incognito is not always hard to penetrate. The real labour is to remember, to attend. In fact, to come awake... (Sibley 1994:52) 
Indeed, the image of Aslan became so real to some that one American mother wrote about her concerns for her 9-yearold son who stated that he loved Aslan more than Jesus (Jacobs 2005:225). Lewis sensitively responded:

But Laurence can't really love Aslan more than Jesus, even if he feels that's what he's doing. For the things he loves Aslan for doing or saying are simply the things Jesus really did and said. So that when Laurence thinks he is loving Aslan, he is really loving Jesus: and perhaps loving Him more than he ever did before. (Jacobs 2005:289)

\section{Conclusion}

In conclusion, C.S. Lewis' designed his magical Aslan, King of Narnia and other worlds, to symbolically represent the biblical Lion of Judah in order to awaken in the reader a quest for knowledge and an understanding of the divine. He was hoping through myth and metaphor to create 'rudimentary impressions designed to show the root of things and open vistas for infinite meditative reflection' (Stegmann et al. 1972:10). By transporting his readers to a world encompassing the divine and demonic in mythological proportions, he hoped to avoid those watchful dragons who stole child-like faith, and thereby ensure that the Christ could be understood and embraced.

\section{Acknowledgements Competing interests}

The author declares that she has no financial or personal relationships that may have inappropriately influenced her in writing this article.

\section{References}

Alkaaoud, E.F., 1984, “'What the lyon ment": Iconography of the Lion in the poetry of Edmund Spenser', Dissertation, Rice University, viewed 28 September 2018, from http://hdl.handle.net/1911/15797

'Animals in the Bible', 2005, New advent: Catholic Encyclopedia, viewed 22 August 2005, from http://www.newadvent.org/cathen/01517a.htm.

Ayres, M., 2016, 7 Sacred animals from around the world, viewed 28 September 2018, from https://animalogic.ca/blog/7-sacred-animals-from-around-the-world.

Barfield, O., 1989, Owen Barfield on C.S. Lewis, Wesleyan University Press, Middletown, CT.

Bongela, K.S., 2001, Isihlonipho among the AmaXhosa, Doctoral thesis in Literature and Philosophy in African Languages, University of South Africa, Pretoria.
Edwards, B., 2005, C.S. Lewis and the case for responsible scholarship, viewed 03 January 2019, from http://personal.bgsu.edu/ edwards/seattle.html.

Frink, H., 1987, Animal symbolism in Hofmannsthal's works, Lang, New York.

Goodwin, C., 2004, 'Representations of Satan in the Narnia Chronicles by C.S. Lewis', MA English Literature, Rand Afrikaans University, Johannesburg.

Huberman, I., 1988, Living symbols: Symbols in Jewish art and tradition, Massada, Ramat-Gan

Jacobs, A., 2005, The Narnian, Harper Collins, San Francisco, CA.

Kuper, H., 1973, 'Costume and cosmology: The animal symbolism of the Ncwala', Man 8(4), 613-630.

Ladner, G.B., 1975, 'Animals in art and thought to the end of the Middle Ages', Speculum 50(4), 732-738.

Lewis, C.S., 1964, Letters to Malcolm, Chiefly on prayer, Geofrey Bles, London.

Lewis, C.S., 1966a, On stories and other essays on literature, Harcourt Books, Orlando, FL.

Lewis, C.S., 1966b, Studies in Medieval and Renaissance literature, Cambridge University Press, Cambridge.

Lewis, C.S., 1967, The discarded image, Cambridge University Press, London.

Lewis, C.S., 1970a, 'Myth became fact', in W. Hooper (ed.), God in the dock: Essays on theology and ethics, Eerdmans Publishing Company, London.

Lewis, C.S., 1970b, Prince Caspian, MacMillan Publishing, New York.

Lewis, C.S., 1970c, The horse and his boy, MacMillan Publishing, New York.

Lewis, C.S., 1970d, The last battle, MacMillan Publishing, New York.

Lewis, C.S., 1970e, The lion, the witch, and the wardrobe, MacMillan Publishing, New York.

Lewis, C.S., 1970f, The magician's nephew, MacMillan Publishing, New York.

Lewis, C.S., 1970g, The silver chair, MacMillan Publishing, New York.

Lewis, C.S., 1970h, The voyage of the Dawn Treader, MacMillan Publishing, New York.

Lewis, C.S., 1979, 'Letter to Arthur Greeves (29 December 1935)', in W. Hooper (ed.), They stand together: The letters of C.S. Lewis to Arthur Greeves (1914-1963), p. 477, MacMillan Publishing, New York.

'Lions in Jewish Art', 2005, Jewish Heritage Online Magazine, viewed 24 August 2005, from http://www.jhom.com/topics/lions/art.htm.

Marotti, A.F., 1965, 'Animal symbolism in the Faerie Queene: Tradition and the poetic context', Studies in English Literature, 1500-1900 5(1), 69-86.

'Mummy Shows Pharaohs Worshipped King of Beasts', 2004, ABC News Online, 14 January, viewed 08 August 2005, from http://abc.net.au/news/newsitems/ s1025596.htm.

Renton, J., 2001, 'The story behind the Potter legend: JK Rowling talks about how she created the Harry Potter books and the magic of the Harry Potter's world', Sydney Morning Herald, 28 October, viewed n.d., from http://www.accio-quote.org/ articles/2001/1001-sydney-renton.htm.

Ring, G., 1945, 'St. Jerome extracting the thorn from the lion's foot', The Art Bulletin 27(3), 188-194.

Rogers, E., 1985, 'Don Quijote and the peaceable lion', Hispania 68(1), 9-14.

Sibley, B., 1994, C.S. Lewis - Through the Shadowlands, Fleming H. Revell, Grand Rapids, MI.

Slotten, R.L., 1965, 'The master of animals: A study in the symbolism of ultimacy in primitive religion', Journal of Bible and Religion 33(4), 293-302.

Stegmann, A., Coursodon J. \& Miller, E., 1972, 'Richness and ambivalence of the symbol in the Renaissance', Yale French Studies 47, 5-18.

Warren, P.N., 2000, 'King of beasts: Manipulation of the lion symbol by patriarchal culture', Mythosphere 2(1), 73-83.

Williams, C., 1931, The place of the lion, Victor Gollancz, London. 